\title{
ЗМІНИ АНТИОКСИДАНТНО-ПРООКСИДАНТНОЇ СИСТЕМИ ТА ЇХ МЕДИКАМЕНТОЗНА КОРЕКЦІЯ ПРИ ПОЄДНАННІ СЕЧОКАМ'ЯНОЇ ХВОРОБИ І ПАРОДОНТИТУ
}

Вступ. У цій статті наведено результати біохімічних досліджень ензимів, проміжних та кінцевих продуктів прооксидантно-пероксидних процесів при захворюваннях пародонта на фроні уролітіазу в динаміці лікування і аспекті об'єктивізації порівняння медикаментозних схем: стандартної загальноприйнятої і розробленої патогенетичної. Представлені дані являють собою фрагмент науково-практичного дослідження, виконаного з метою вдосконалення пародонтологічної допомоги при сечокам'яній хворобі.

Мета дослідження - вивчити й проаналізувати стан ензиматичної ланки системи антиоксидантного захисту й інтенсивність окисних процесів у пацієнтів із сечокам'яною хворобою і патологією пародонта, з'ясувати ефрективність комбінованої фрармакотерапії при захворюваннях пародонта на фроні сечокам'яної хвороби.

Mетоди дослідження. Біоматеріал досліджено в 60 пацієнтів із запальними захворюваннями пародонта на фроні сечокам'яної хвороби. Для лікування хворих застосовано дві різні фрармакотерапевтичні схеми. 3 метою об'єктивізації результатів проведено ряд біохімічних досліджень. Зәідно з отриманими даними, використання розробленої схеми лікування в пацієнтів із коморбідною патологією забезпечувало нормалізацію системи антиоксидантного захисту за показниками каталази $(3(1,99 \pm 0,14)$ мкM/хв×мг гемоглобіну на початку лікування до $(1,66 \pm 0,04)$ мкМ/хв×мг гемоглобіну після лікування) та супероксиддисмутази (з $(1,40 \pm 0,12)$ до $(2,10 \pm 0,07)$ МО/мг гемоглобіну), а також зниження рівнів проміжних і кінцевих продуктів пероксидного окиснення.

Результати й обговорення. Аналіз результатів спостереження засвідчив високу ефективність комбінованої фрармакотерапії.

Висновки. Застосування стандартної та розробленої схем лікування забезпечувало нормалізацію активності ензиматичної ланки системи антиоксидантного захисту і знижувало інтенсивність окисних процесів. Аналіз результатів досліджень свідчить про вищу ефективність комбінованої фрармакотерапії, оскільки показники системи антиоксидантного захисту у хворих, пролікованих за розробленою схемою, нормалізувались швидше, ніж при використанні традиційного загальноприйнятого протоколу.

КЛЮчОВІ СЛОВА: захворювання пародонта; сечокам'яна хвороба; комбінована фрармакотерапія; пероксидне окиснення ліпідів.

ВСТУП. Для України проблема захворювань пародонта (ЗП) не втрачає своєї актуальності. Їх частота в людей віком до 40 років становить 50-60 \%, а у старших вікових групах - $100 \%$ [1].

Доведено, що на розвиток і перебіг ЗП впливає наявність такої системної та органної соматичної патології, як цукровий діабет, захворювання органів шлунково-кишкового тракту, ендокринні хвороби, хронічний гломерулонефрит, сечокам'яна хвороба та ін. [2]. Загальносоматичні захворювання чинять значний вплив на патологічний процес у тканинах пародонта, формують клінічну картину і перебіг запалення [3].

(с) 3. О. Бумбар, О. Р. Піняжко, 2017.
Захворюванням пародонта і сечокам'яній хворобі властивий хронічний рецидивний перебіг, при цьому системний уролітіаз спричинює особливі порушення водно-сольового метаболізму, оксидантного гомеостазу і гемоциркуляції, що становлять патогенетичне обтяження для функціонування зубоутримувальних тканин.

На сьогодні встановлено, що більшість захворювань організму, зокрема всі типи запалення, зміни функціонального стану органів та тканин, розвиваються на фоні зниження показників системи антиоксидантного захисту (АОЗ) при посиленні вільнорадикальних процесів, що, у свою чергу, призводить до накопичення в тка- 
нинах токсичних продуктів окиснення, порушення метаболізму й ускладнює перебіг захворювань. Вільні радикали, до яких належать активні форми оксисену, постійно утворюються в організмі та є учасниками багатьох фрізіологічних процесів. Головну роль у підтриманні оптимального рівня вільних радикалів і, відповідно, регуляції пероксидного окиснення ліпідів (ПОЛ) відіграють ензими системи АОЗ: супероксиддисмутаза (СОД), глутатіонпероксидаза (ГПО), каталаза (КАТ).

Патогенетично обґрунтований вибір біологічно активних речовин, які використовують для місцевого і загального лікування ЗП, зумовлений необхідністю діяти як на запалення, так і на дистрофрічні процеси [4], відповідно, біологічна активність медикаментів визначається патогенетичною спрямованістю ліків, а лікарська фрорма - методикою застосування. Перспективним і актуальним спільним завданням клінічної фрармакології та стоматології є розробка ефрективних схем лікування, що відповідають специфічним умовам використання медикаментозних засобів.

Мета дослідження - вивчити й проаналізувати стан ензиматичної ланки системи антиоксидантного захисту й інтенсивність окисних процесів у пацієнтів із сечокам'яною хворобою і патологією пародонта, з'ясувати ефективність комбінованої фрармакотерапії при захворюваннях пародонта на фроні сечокам'яної хвороби.

МЕТОДИ ДОСЛІДЖЕННЯ. СТан енЗИматичної ланки системи АОЗ та інтенсивність окисних процесів у крові пацієнтів із сечокам'яною хворобою [N20-N23] і патологією пародонта [K05 (К05.1, К05.3)] проаналізовано в 60 осіб. Хворих поділили, залежно від застосованої фрармакотерапії, на 2 групи по 30 осіб у кожній. Групи були зіставні за особовою та діагностичною структурою. Загальне лікування урологічної патології проводив лікар-інтерніст в умовах урологічного відділення денного стаціонару Комунальної міської клінічної лікарні швидкої медичної допомоги м. Львова. Воно складалося із спазмолітичної, антибактеріальної та протизапальної терапії з використанням нефропротектора "Уролесан". Стандартна схема лікування ЗП включала загальноприйнятий комплекс заходів і середників (Додаток до наказу МОЗ України від 22.11.2000 р. № 305). У розроблену схему було введено лікарську композицію у формі спрею із вмістом тіотриазоліну [5] як патогенетичного антиоксидантного медикаментозного засобу.

Лікування 3П та лабораторні дослідження проводили з метою верифрікації розробленої схеми комбінованої фрармакотерапії при коморбідній патології на стадії ремісії уролітіазу.
Біохімічні показники системи АОЗ та рівні процесів ПОЛ визначали до і безпосередньо після лікування, а також через 6 місяців для отримання віддалених результатів: 1) до лікування в умовах урологічного стаціонару, тобто до лікування 3П; 2) безпосередньо після пародонтологічного лікування й у віддалений після пародонтологічної курації та досягнення ремісії шестимісячний термін згідно з диспансерним контролем основної патології в дільничних лікувальних установах і, відповідно, на обладнанні лабораторій цих закладів.

Вивчали такі показники ензиматичних ланок АОЗ - ПОЛ: у цільній крові - активність ензимів антиоксидантного захисту: супероксиддисмутази [6], глутатіонпероксидази [7], каталази [8]; у плазмі крові - вміст продуктів ПОЛ (дієнових кон'югатів, гідропероксидів ліпідів), вміст ТБК-активних продуктів (малонового діальдегіду).

Усі дослідження виконували відповідно до методик і вимог ДФЦ МОЗ України та згідно 3 Директивою Європейського Союзу 2010/10/63 EU. Протокол проведення досліджень затвердила Комісія з біоетики Львівського національного медичного університету імені Данила Галицького (протокол № 8 від 18 вересня 2017 р.)

Статистичну обробку матеріалів проводили за допомогою комп'ютерної програми Statistica 8.0. Результати визначали для середніх (за t-критерієм Стьюдента) і відносних (за кутовим перетворенням Фішера $(\varphi))$ величин статистичним методом варіаційних рядів з використанням критерію Манна-Уїтні. Результати наведено у вигляді $\mathrm{M} \pm \mathrm{m}$, де $\mathrm{M}$ - вибіркове середнє, $\mathrm{m}$ - помилка середнього. Зміни вважали статистично значущими при $p<0,05$ [9].

РЕЗУЛЬТАТИ Й ОБГОВОРЕННЯ. ЦИфрові дані досліджуваних біохімічних показників у пацієнтів у динаміці лікування та їх статистичні порівняння з рівнями фрізіологічної норми у здорових осіб наведено в таблиці.

Аналіз конкретних показників виявив, що активність СОД безпосередньо після проведеного розробленого лікування зростала на 50,0 \% $(p<0,001)$, тоді як за протокольного лікування - на 21,4 \% ( $<<0,01)$. У віддалені терміни медикаментозної терапії величини показника в обох групах вірогідно не відрізнялись від рівнів фрізіологічної норми і були вищими, порівняно з початком лікування, у 2,2 раза ( $p<0,001)$.

Активність КАТ після застосування як стандартної, так і розробленої схем лікування знижувалася на 10,6 та 16,6 \% (p<0,05), а через 6 місяців досягала контрольних значень і зменшувалася на 22,6 та 25,6 \% (p<0,001) відповідно порівняно з величинами показника до лікування. 
Таблиця - Активність ензимів системи антиоксидантного захисту і вміст продуктів пероксидного окиснення ліпідів у крові пацієнтів із сечокам'яною хворобою і патологією пародонта під час лікування

\begin{tabular}{|c|c|c|c|c|c|c|}
\hline Показник & $\begin{array}{c}\text { Схема } \\
\text { лікування }\end{array}$ & $\mathrm{n}$ & До лікування & $\begin{array}{c}\text { Після } \\
\text { лікування }\end{array}$ & $\begin{array}{c}\text { У віддалені } \\
\text { терміни } \\
\text { лікування }\end{array}$ & Контроль \\
\hline \multirow{2}{*}{$\begin{array}{l}\text { СОД, МО/мг } \\
\text { гемоглобіну }\end{array}$} & стандартна & 30 & \multirow[t]{2}{*}{$1,40 \pm 0,12$} & $1,70 \pm 0,09 * \star$ & $3,01 \pm 0,03^{\star \star \star}$ & \multirow[t]{2}{*}{$3,16 \pm 0,18$} \\
\hline & розроблена & 30 & & $2,10 \pm 0,07^{\star \star \star}$ & $3,14 \pm 0,04^{\star \star \star}$ & \\
\hline \multirow{2}{*}{$\begin{array}{l}\text { КАТ, мкМ/Хв×мг } \\
\text { гемоглобіну }\end{array}$} & стандартна & 30 & \multirow[t]{2}{*}{$1,99 \pm 0,14$} & $1,78 \pm 0,03$ & $1,54 \pm 0,02^{\star \star}$ & \multirow[t]{2}{*}{$1,44 \pm 0,06$} \\
\hline & розроблена & 30 & & $1,66 \pm 0,04^{*}$ & $1,48 \pm 0,03^{\star \star \star}$ & \\
\hline \multirow{2}{*}{$\begin{array}{l}\text { ГПО, мкМ/хв×мг } \\
\text { гемоглобіну }\end{array}$} & стандартна & 30 & \multirow[t]{2}{*}{$0,372 \pm 0,035$} & $0,311 \pm 0,020$ & $0,234 \pm 0,019^{\star \star \star \star}$ & \multirow[t]{2}{*}{$0,200 \pm 0,025$} \\
\hline & розроблена & 30 & & $0,302 \pm 0,018$ & $0,210 \pm 0,029^{\star \star \star}$ & \\
\hline \multirow{2}{*}{$\begin{array}{l}\text { Дієнові кон'югати, } \\
\text { нМ/мл }\end{array}$} & стандартна & 30 & \multirow[t]{2}{*}{$119,7 \pm 3,12$} & $99,4 \pm 2,14^{\star \star \star}$ & $65,1 \pm 4,33^{\star \star \star}$ & \multirow[t]{2}{*}{$51,3 \pm 4,67$} \\
\hline & розроблена & 30 & & $81,3 \pm 1,99 * \star \star$ & $54,9 \pm 3,24^{\star \star \star}$ & \\
\hline \multirow{2}{*}{$\begin{array}{l}\text { Гідропероксиди } \\
\text { ліпідів, Од. }{ }_{480} / \mathrm{M} л\end{array}$} & стандартна & 30 & \multirow[t]{2}{*}{$2,14 \pm 0,25$} & $1,89 \pm 0,17$ & $1,01 \pm 0,07^{\star \star \star}$ & \multirow[t]{2}{*}{$0,59 \pm 0,10$} \\
\hline & розроблена & 30 & & $1,75 \pm 0,14$ & $0,79 \pm 0,08^{\star \star \star}$ & \\
\hline \multirow{2}{*}{$\begin{array}{l}\text { ТБК-активні } \\
\text { продукти, нМ/мл }\end{array}$} & стандартна & 30 & \multirow[t]{2}{*}{$1,82 \pm 0,27$} & $1,66 \pm 0,11$ & $0,61 \pm 0,05^{\star \star \star}$ & \multirow[t]{2}{*}{$0,52 \pm 0,11$} \\
\hline & розроблена & 30 & & $1,47 \pm 0,09$ & $0,54 \pm 0,04^{\star \star \star}$ & \\
\hline
\end{tabular}

Примітки:

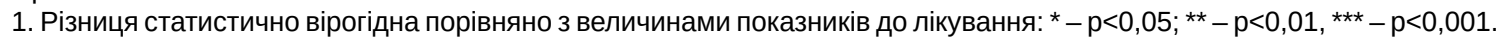

2. Контроль - фрізіологічна норма для клінічно здорових осіб відповідно до методики і калібрування приладу.

Як показали результати досліджень активності ГПО у крові хворих, її зміни були подібними до динаміки активності КАТ. Висока активність ензиму на початку лікування знижувалася в обох групах на 16,2 та 18,8 \%, а через 6 місяців величини показника відповідали контрольним значенням і були меншими, порівняно з вихідними, на 37,1 та $46,5 \%(p<0,001)$ відповідно.

Слід відмітити, що активність СОД у хворих, яких лікували за розробленою схемою, наприкінці шостого місяця лікування була тенденційно вищою (на 4,3 \%) від величин показника в пацієнтів, пролікованих за стандартною схемою, а активність КАТ та ГПО, відповідно, нижчою на 3,9 i $10,3 \%$.

Виявлені особливості активності досліджуваних антиоксидантних ензимів у крові пацієнтів із сечокам'яною хворобою та патологією пародонта в динаміці лікування підтверджувалися змінами вмісту проміжних (дієнових кон'югатів і гідропероксидів ліпідів) та кінцевих (ТБК-активних) продуктів пероксидного окиснення ліпідів, до яких належать малоновий діальдегід та інші альдегіди.

Так, найвищим вмістом дієнових кон'югатів характеризувалася плазма крові хворих до лікування $((119,7 \pm 3,12)$ нМ/мл) (табл.). Безпосередньо після лікування вміст дієнових кон'югатів знижувався на $17,0 \%(p<0,001)$ та $32,0 \%$ $(p<0,001)$, через 6 місяців після лікування він був меншим в $1,8(p<0,001)$ і 2,2 раза $(p<0,001)$, порівняно з вихідними значеннями, відповідно у хворих, яких лікували за стандартною та розробленою схемами, і вірогідно не відрізнявся від контрольних.

Аналогічну динаміку встановлено для вмісту гідропероксидів ліпідів у плазмі крові хворих: величини показника були найвищими на початку лікування - $(2,14 \pm 0,2)$ Од. 480 Мл, що більше в 3,6 раза від контрольних значень, тенденційно знизились на 11,7 \% після лікування в протокольній (стандартній) групі хворих і на $18,2 \%$ у групі розробленої фрармакотерапії, а через 6 місяців вміст гідропероксидів ліпідів ще зменшився, порівняно з показником до початку лікування, в 2,1 та 2,8 раза $(p<0,001)$, однак залишився дещо вищим від величин у клінічно здорових осіб - в 1,7 і 1,3 раза відповідно.

Кінцевою стадією пероксидного окиснення ліпідів $€$ утворення альдегідів, серед яких у кількісному відношенні переважає малоновий діальдегід (ТБК-активні продукти). Встановлено, що вміст ТБК-активних продуктів у плазмі крові хворих був найвищим на початку лікування i становив $(1,82 \pm 0,27)$ нМ/мл. Безпосередньо після лікування він знижувався на 8,8 та 19,2 \% у групах спостереження, через 6 місяців був меншим від початкового в 3,0 і 3,4 раза та вірогідно не відрізнявся від величин показника у клінічно здорових осіб.

ВИСНОВКИ. 1. У ході лікування пародонтиту на фоно сечокам'яної хвороби спостерігали нормалізацію активності ензиматичної ланки системи антиоксидантного захисту i зростання показника супероксиддисмутази 3 $(1,40 \pm 0,12)$ MO/мг гемоглобіну на початку лікування до $(3,14 \pm 0,04) \mathrm{MO} / \mathrm{Mг}$ гемоглобіну після лікування у групі, в якій застосовували комбіновану фрармакотерапію.

2. За рівнями каталази і глутатіонпероксидази відзначено зниження окисних процесів 3 $(1,99 \pm 0,14)$ та $(0,372 \pm 0,035)$ до $(1,48 \pm 0,03)$ i $(0,210 \pm 0,029)$ МкМ/хв×мг гемоглобіну відповідно. 
3. Показники системи пероксидного окиснення ліпідів за рівнями проміжних (дієнових кон'югатів) та кінцевих (ТБК-активних, малонового діальдегіду) продуктів представляли картину регуляції прооксидантного статусу при впливі формакотерапії.

4. Загалом аналіз стану ензиматичної ланки системи антиоксидантного захисту та інтенсивності окисних процесів у пацієнтів із сечокам'яною хворобою і патологією пародонта свідчив про позитивні зміни, які відбулись при лікуванні.

5. Проведена терапія сприяла зниженню інтенсивності процесів пероксидного окиснення як на проміжних, так і на кінцевих ланках, а в цифровому вираженні цей вплив був більш вираженим при включенні у медикаментозну терапію тіотриазоліну.

6. Аналіз результатів досліджень свідчить про вищу ефеективність комбінованої фрармакотерапії, оскільки показники системи антиоксидантного захисту у хворих, пролікованих за розробленою схемою, нормалізувались швидше, ніж при використанні традиційного загальноприйнятого протоколу.

Перспективи подальших досліджень удосконалення лікувальних схем для попередження захворювань пародонта при сечокам'яній хворобі.

\section{СПИСОК ЛІТЕРАТУРИ}

1. Поворознюк В.В.Структурно-фрункціональний стан кісткової тканини та тканин пародонта під час вагітності та лактації / В. В. Поворознюк, О. В. Фліс // Вісн. Вінниц. держ. мед. ун-ту. - 2002. - 6, № 1. C. 201.

2. Горбачева И. А. Единство системных патогенетических механизмов при заболеваниях внутренних органов, ассоциированных с генерализованным пародонтитом / И. А. Горбачева, А. И. Кирсанов, Л. Ю. Орехова // Стоматология. - 2005. - № 5. - С. 24-29.

3. Зв'язок захворювань пародонта з загальносоматичною патологією (огляд літератури) / О. М. Немеш, 3. М. Гонта, І. В. Шилівський, А. П. Скалат // Новини стоматології. - 2006. - № 2. - С. 34-37.

4. Стоматологія : підручник : у 2 кн. / [М. М. Рожко, І. І. Кириленко, О. Г. Денисенко та ін.] ; за ред. М. М. Рожка. - К. : ВСВ "Медицина", 2013. - Кн. 2. - 992 с.

5. Пат. 103627, UA, МПК (2015.01), A61P 31/02 (2006.01), A61K 31/00, A61K 9/12 (2006.01), A61K 35/00,
A61P 1/02 (2006.01). Засіб у формі спрею для терапії запальних та дистрофрічно-запальних захворювань тканин пародонта / Федін Р. М., Бумбар 3. О., Піняжко О.Р. - Власник Львівський національний медичний університет імені Данила Галицького. - № u 201505834 ; заявл. 15.06.15 ; опубл. 25.12.15, Бюл. № 24.

6. Чевари С. Н. Определение антиоксидантных параметров крови и их диагностическое значение в пожилом возрасте / С. Н. Чевари, Т. А. Андян, Я. И. Штренгер // Лаб. дело. - 1991. - № 10. - С. 9-13.

7. Моин В. М. Простой и специфрический метод определения глутатионпероксидазы в эритроцитах / В. М. Моин // Лаб. дело. - 1986. - № 12. - С. 16-19.

8. Метод определения активности каталазы / М. А. Королюк, Л. И. Иванова, И. Г. Майорова, В. Е. Токарев // Лаб. дело. - 1991. - № 12. - С. 9-10.

9. Боровиков В. Statistica: Искусство анализа данных на компьютере. Для профрессионалов / В. Боровиков. - СПб. : Питер, 2001. - 656 с.

\section{REFERENCES}

1. Povorozniuk, V.V. \& Flis, O.V. (2002). Strukturnofunktsionalnyi stan kistkovoi tkanyny ta tkanyn parodonta pid chas vahitnosti ta laktatsii [Structural-functional state of bone tissue and periodontal tissues during pregnancy and lactation]. Visnyk Vinnytskoho derzhavnoho medychnoho universytetu - Journal of Vinnytsia State Medical University, 1, 201 [in Ukrainian].

2. Horbacheva, I.A., Kirsanov, A.I. \& Orekhova, L.Yu. (2005). Yedinstvo sistemnykh patogeneticheskikh mekhanizmov pri zabolevaniyakh vnutrennikh organov, assotsiirovannykh $s$ generalizovannym parodontitom [Unity of systemic pathogenetic mechanisms in diseases of internal organs associated with generalized periodontitis]. Stomatologiya - Dentistry, 5, 24-29 [in Russian].

3. Nemesh, O.M., Honta, Z.M., Shylivskyi, I.V. \& Skalat, A.P. (2006). Zviazok zakhvoriuvan parodonta z zahalnosomatychnoiu patolohiieiu (ohliad literatury) [Relationship of periodontal diseases with general-pathology (review of literature)]. Novyny stomatolohii-Dentistry News, 2, 34-37 [in Ukrainian].

4. Rozhko, M.M., Kyrylenko, I.I. \& Denysenko, O.H. (2013). Stomatolohiia: pidruchnyk: U 2 kn. Kn. 2. [Dentistry: textbook: 2 books. Book 2]. (Ed.) Rozhko, M.M. Kyiv: VSV "Medytsyna" [in Ukrainian]. 
5. Fedin, R.M., Bumbar, Z.O. \& Piniazhko, O.R. (2015). Zasib u formi spreiu dlia terapii zapalnykh ta dystrofichno-zapalnykh zakhvoriuvan tkanyn parodonta [Spray remedy for the treatment of inflammatory and dystrophic-inflammatory diseases of periodontal tissues]. Pat. № 103627, UA, MPK (2015.01), A61R 31/02 (2006.01), A61K 31/00, A61K 9/12 (2006.01), A61K 35/00, A61R 1/02 (2006.01). Vlasnyk Lvivskyi natsionalnyi medychnyi universytet imeni Danyla Halytskoho, № u 2015 05834; zaiavl. 15.06.2015; opubl. 25.12.2015, Biul. № 24. - Owner Danylo Halytskyi Lviv National Medical University, № 2015 05834; stated. June 15, 2015; has published 25.12.2015, Bul. No. 24 [in Ukrainian].

6. Chevari, S.N., Andyan, T.A. \& Shtrenger, Ya.I. (1991). Opredeleniye antioksidantnikh parametrov krovi i ikh diagnosticheskoye znacheniye $v$ pozhilom vozraste [Determination of antioxidant blood parameters and their diagnostic value in the elderly]. Lab. Delo - Laboratory Work, 10, 9-13 [in Russian].

7. Moin, V.M. (1986). Opredeleniye antioksidantnikh parametrov krovi i ikh diagnosticheskoye znacheniye $\mathrm{v}$ pozhilom vozraste [Simple and specific method of determination of glutathione peroxidase in erythrocytes]. Lab. Delo - Laboratory Work, 12, 16-19 [in Russian].

8. Korolyuk, M.A., Ivanova, L.I., Mayorova, I.G. \& Tokarev V.E. (1991). Prostoy i spetsificheskiy metod opredeleniya glutationperoksidazy v eritrotsitakh [Method for determining the activity of catalase]. Lab. Delo Laboratory Work, 12, 9-10 [in Russian].

9. Borovikov, V. (2001). Statistika: iskusstvo analiza dannykh na kompyutere. Dlya professionalov. [Statistics: the art of analyzing data on a computer. For professionals]. St. Petersburg: Piter [in Russian].

\section{ИЗМЕНЕНИЯ АНТИОКСИДАНТНО-ПРООКСИДАНТНОЙ СИСТЕМЫ И ИХ МЕДИКАМЕНТОЗНАЯ КОРРЕКЦИЯ ПРИ СОЧЕТАНИИ МОЧЕКАМЕННОЙ БОЛЕЗНИ И ПАРОДОНТИТА}

\section{Резюме}

Вступление. В этой статье приведены результаты биохимических исследований энзимов, промежуточных и конечных продуктов прооксидантно-перекисных процессов при заболеваниях пародонта на фроне уролитиаза в динамике лечения и аспекте объективизации сравнения медикаментозных схем: стандартной общепринятой и разработанной патогенетической. Представленные данные являются фррагментом научно-практического исследования, выполненного с целью усовершенствования пародонтологической помощи при мочекаменной болезни.

Цель исследования - изучить и проанализировать состояние энзиматического звена системы антиоксидантной защиты и интенсивность окислительных процессов у пациентов с мочекаменной болезнью и патологией пародонта, выяснить эфрфективность комбинированной фрармакотерапии при заболеваниях пародонта на фооне мочекаменной болезни.

Методы исследования. Биоматериал исследован в 60 пациентов с воспалительными заболеваниями пародонта на фроне мочекаменной болезни. Для лечения больных применены две разные фрармакотерапевтические схемы. С целью объективизации результатов проведен ряд биохимических исследований. Согласно полученным данным, использование разработанной схемы лечения у пациентов с коморбидной патологией обеспечивало нормализацию системы антиоксидантной защиты по показателям каталазы (с $(1,99 \pm 0,14)$ мкM/мин×мг гемоглобина в начале лечения до $(1,66 \pm 0,04)$ мкM/мин×мг гемоглобина после лечения) и супероксиддисмутазы (с $(1,40 \pm 0,12)$ до $(2,10 \pm 0,07)$ ME/мг гемоглобина), а также снижение уровней промежуточных и конечных продуктов перекисного окисления.

Результаты и обсуждение. Анализ результатов наблюдения показал высокую эффективность комбинированной фрармакотерапии.

Выводы. Применение стандартной и разработанной схем лечения обеспечивало нормализацию активности энзиматического звена системы антиоксидантной защиты и снижало интенсивность окислительных процессов. Анализ результатов исследований свидетельствует о высокой эфрфективности комбинированной фрармакотерапии, поскольку показатели системы антиоксидантной защиты у больных, пролеченных по разработанной схеме, нормализовались быстрее, чем при использовании традиционного общепринятого протокола.

КЛЮЧЕВЫЕ СЛОВА: заболевания пародонта; мочекаменная болезнь; комбинированная фармакотерапия; перекисное окисление липидов. 


\section{CHANGES OF ANTIOXIDANT-PROOXIDANT SYSTEM AND ITS MEDICAMENTAL CORRECTION WITH COMBINATION OF UROLITHIASIS AND PERIODONTITIS}

\section{Summary}

Introduction. The article presents the results of biochemical studies of enzymes, intermediate and final products of prooxidant-peroxidic processes in periodontal diseases against the background of urolithiasis in the dynamics of treatment and in the aspect of the presenting of comparison of two drug regimens: standard common and developed pathogenetic. The presented data represent a fragment of the scientific and practical research performed to improve the periodontal care in patients with urolithiasis.

The aim of the study - to analyze the biochemical studies performed in patients with comorbid pathology after combined pharmacotherapy. The biomaterial was studied in 60 patients with inflammatory periodontal diseases on the background of urolithiasis. Two different pharmacotherapeutic regimens were used to treat patients.

Research Methods. A series of biochemical studies was carried out to objectify the results. According to the obtained data, the application of the developed treatment regimen in patients with comorbid pathology provided normalization of the antioxidant protection system in catalase parameters from $(1.99 \pm 0.14)$ at the beginning of treatment to (1.66 \pm 0.04$)$ after treatment and superoxidedismutase from $(1.40 \pm 0.12)$ to (2.10 \pm 0.07$)$, as well as a decrease in the levels of intermediate and final products of peroxidation.

Results and Discussion. The analysis of the results of the observation showed high efficiency of combined pharmacotherapy.

Conclusions. Thus, according to the resulted biochemical indicators, application of standard and developed treatment regimens ensured the normalization of the activity of the enzymatic level of the antioxidant system and reduced the intensity of the oxidative processes. An analysis of the results of the studies suggests a higher efficiency of the combined pharmacotherapy, since antioxidant protection indicators in patients treated under the developed scheme, normalized faster than when administered under the traditional generally accepted protocol. lipids.

KEY WORDS: periodontal diseases; urolithiasis; combined pharmacotherapy; peroxide oxidation of

Адреса для листування: 3. О. Бумбар, вул. Харківська, 32/2, Львів, 79010, Україна, e-mail: zenysja@gmail.com. 